\title{
Role Of Institutions In Growth Of Countries
}

Tejinder S. Sara, Tuskegee University, USA

Alicia J. Jackson, Susquehanna University, USA

Leo Upchurch, Tuskegee University, USA

Simran Kahai, John Carroll University, USA

\begin{abstract}
The purpose of this paper was to look at the role of institutions in growth of countries. We compared income and quality of institutions' data among 87 developing countries to see if institutions that promote economic freedom and investment lead to higher economic growth. In addition, we wanted to look at the role of institutions in economic growth at the local level in a country. For this analysis, we compared income and quality of institutions' data for different states in India. In both cases, we found that growth is significantly affected by the quality of institutions.
\end{abstract}

Keywords: economic growth, country competitiveness, role of institutions, regression analysis.

\section{INTRODUCTION}

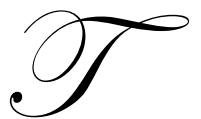

he first decade of the 21 century is a time for both opportunities and turmoil for countries around the globe. A number of developing countries, such as China and India in Asia, Botswana in Africa, and Chile in Latin America, have shown rapid economic growth in the last decade. On the other hand, we find a number of developing countries in Asia, Africa, and Latin America stagnating, and in some cases-such as Myanmar (formerly Burma) in Asia, Zimbabwe in Africa, and Guyana in Latin America-loosing ground. Policy makers in developed and the developing world are seeking explanations for the divergence in the economic fortune of countries.

\section{BACKGROUND}

In recent years, researchers and policy makers have offered two major hypotheses for causes of differences in the incomes of countries. The first, geography hypothesis, maintains that geography, ecology, and climate of a country are the major determining factors in the economic growth of a country. But this hypothesis fails to explain why two neighboring countries with similar geography, ecology, and climate-for example, Thailand and Myanmar in Asia, Botswana and Zimbabwe in Africa, and Chile and Paraguay in South America-have very divergent growth rates. The geography hypothesis maintains that forces of nature are the major determinants of success of a nation, but it cannot account for why some countries in the Far East, such as Hong Kong, Singapore, South Korea, and Taiwan, with meager natural resources developed much faster than Indonesia and Philippines, countries with a much larger endowment of natural resources. We see the same phenomenon in other parts of the world. In Africa, Nigeria with large oil reserves and in South America, Venezuela with the largest oil reserves and Bolivia with the largest gas reserves have faced anemic growth (actually Venezuela had negative economic growth in 2002 and 2003).

Some researchers have offered a second hypothesis for income differences among nations. This hypothesis, usually referred to as the institutions hypothesis, contends that the primary factor for economic development is human influences, rather than geographic and natural resource influences. In this view, what matters most are the rules of games in a society, as defined by prevailing explicit and implicit behavioral norms and their ability to create appropriate incentives for desirable economic behavior (Rodrik and Subramanian, 2003). The basic idea is that countries with institutions that encourage investment will have higher productivity, which in turn will lead to higher economic growth. This is not a new idea. It has been espoused by economists and philosophers for many centuries. Over 300 years ago philosopher John Locke (2003), over 200 years ago economist and philosopher Adam Smith (1994), and 60 ago economist Frederick von Hayek (1944) emphasized the importance of property rights in 
productivity and economic success of nations. Adam Smith said: "Nations will experience opulence and peace once they create the institutions that encourage entrepreneurship and savings." Most of the recent work on the role of institutions in economic growth has been associated with the writings of Nobel Prize winner economist Douglas North (1990). North emphasized the affect of institutional factors on economic development and concentrated on the relationship between economic growth and two institutional factors, namely, political freedom and civil liberty. This was followed by some other studies that extended the role of institutions in economic growth by including economic freedom as a variable affecting economic growth. In particular econometric studies by Acemolugu, Johnson, and Robinson (2002) have emphasized the crucial role of institutions in the development process. As an illustration, one of their studies asks the question why a number of countries that were relatively rich five centuries, ago are relatively poor today. Their research attempts to show that most of these countries were colonized by the European powers starting in the $15^{\text {th }}$ century and this intervention led to a major change in institutions that contributed to the decline of relative income. On the other hand, those lands that were relatively poor at the time of European expansion became relatively richer as a result of colonization. According to the authors, civilizations in North America, Australia, and New Zealand were less developed and sparsely populated. This enabled the Europeans to settle in large numbers and introduce their home country institutions that encouraged investment and business expansion. In these lands Europeans created institutions to support private property and check the power of the state. Civilizations that were relatively rich at the time of European expansion (such as Incas in South America, Aztec in Mexico, and Mughals in India) had large populations making extractive institutions more profitable. The European colonizers changed the existing institutions in these countries, for example, to force the native populations to work in mines or plantations. The most distinguishing feature of these institutions was that power was bestowed on a few who were able to use this power for their personal gain through extraction of gold, silver, cash crops, etc. In many of these lands, institutions created by the colonizers endured after independence.

In another study, Adkins, Moomaw, and Savvides (2002) empirically tested the relationship between economic growth and different measures of economic freedom and human capital. Using data from 73 developed and developing countries for the years 1975, 1980, 1985, and 1990, their study indicated that institutions that promote economic freedom have a positive effect on economic performance. Another finding of this study is that of the dual role of human capital. In particular, the study provides evidence that investment in human capital improves overall efficiency of investment in the economy.

Dawson (1998), using regressions came to the conclusion that economic growth is positively related to economic freedom because of it's positive affect on investment. Rodrick (1997) studied the affect of political factors on economic growth and came to the conclusion that there is a positive relationship between these two variables. In (2000), Rodrick extended his study by defining five types of institutions that affect the efficient functioning of markets. These institutions are: institutions of property rights, institutions of regulations, institutions of macroeconomic stabilization, institutions of social insurance, and institutions of conflict management. A group of studies by Barro and Sala-I-Martin (1995), Gwartney, Lawson, and Block (1996), and Scully (1988) also concluded that an economically free country reduces risk through policies that provides security of property, non-confiscatory taxes, and enforcement of contracts. Two economists with different backgrounds De Soto (2000) and Olson (2000) have made important contributions in answering the question, "Why some economies succeed, while others fail?" De Soto from Peru and Olson from the United States argue that the main difference between the two economies is institutions.

\section{COUNTRY COMPETITIVENESS AND ECONOMIC GROWTH}

It is well recognized that productivity of a country is the key to its economic growth and level of prosperity. Many researchers and writers in the area of economic development write and speak about competitive advantage of nations, but nations do not compete with each other. The individual firms in those nations fight the competitive battles. For example, South Korea does not compete with Japan for share of the global electronics market. It is South Korean electronics firms, such as Samsung that compete against Japanese electronics firms such as Sony. Kenya does not compete with Sri Lanka for share of the world tea market. It is the tea plantations of Kenya and Sri Lanka that compete with each other to harvest, process, and deliver to the consumers the best quality tea at competitive prices. Thus, the unit of analysis in seeking keys to a country's growth and prosperity must start with its firms. The question of interest is what conditions in a country will make its firms more competitive in a global economy. 
Conventional solutions, by focusing mostly on economic aggregates have failed to address the real causes of low economic growth and poverty in a number of countries. Since individual firms create jobs and growth in a country, it is essential to study the functioning of these firms. If the firms in a country are productive and growing, the country in aggregate will have a higher growth rate. On the other hand, if the firms in a country are stagnating, or are engaged in unproductive activities, the country will be mired in poverty. So, the key to a country's prosperity is the productivity of its firms. Many a times studies on economic prosperity of countries focuses only on macroeconomic variables, such as, budget deficits, interest rates, tariffs, etc. There is no denying that these are important variables for growth, but they ignore the roots causes of productivity of the firms. If a country does not have in place institutions that affect the efficient functioning of markets, firms in that country will concentrate on making money by exploiting non productive activities, such as, bribery, tax evasion, political favors, etc. Even though these kinds of behavior can generate profits for select firms, it undermines the common good. We contend that countries with good institutions have higher investment in human capital, machinery, technology, infrastructure, and other factors that lead to higher productivity of its firms which, in turn, determines the development of a country.

\section{EMPIRICAL MODEL}

This section presents two empirical models that we use to describe the role of institutions in level of income in developing countries.

\section{Model 1}

The World Economic Forum has been measuring national competitiveness for over two decades. The methodology has changed over the years, by incorporating the latest thinking about what derives the underlying productivity of a nation. Since 2001, the methodology has been based on a model developed by Jeffery Sachs and John McArthur, called the Growth Competitiveness Index (GCI). The GCI uses a combination of hard data and data drawn from the World Economic Forum's Executive Opinion Survey. The Survey attempts to capture concepts for which hard data may not be available, but is essential for economic growth (for example, prevalence of institutionalized corruption, government waste, and enforcement of contracts and laws). In addition, it has data on other variables essential for competitiveness for a country's business firms. We regressed per capita gross national income adjusted for purchasing power parity and two variables that we believe are important determinants of income level in developing countries. These two variables are an index for quality of public institutions and an index for quality of macroeconomic environment. Components of the Index for public institutions include independence of judiciary from political influences, protection of assets, government neutrality in awarding of contracts, cost of organized crime in conduct of business, the prevalence of bribes in conduct of different phases of business. Macroeconomic index include data on variables such as national savings rate, inflation, government surplus/deficit, real effective exchange rate, government debt and lending-borrowing interest rate spread. Table 1 provides variable names and definitions for 87 developing countries used in Model 1. Results of regression for Model 1 are presented in Table 2.

\section{Model 2}

In addition, to looking at the role of institutions in economic growth of developing countries, we wanted to look within a country to study the role of institutions in growth of different regions of a country. This is because a number of fast growing countries have had uneven growth among different regions. We believe that the type of institutions a country has are as much a consequence of the policies of the central government of a country as it is the results of the acts of the state governments. We were interested in seeing if differences in institutions of local governments affected the growth of different parts of a country.

Even though India has been one of the fastest growing countries in recent years, there has been uneven growth between different states of that country. Some states are growing very fast while others are lagging. We used data on the income levels and scores on certain institution variables of different states in India to evaluate the role of "good institutions" on varying growth rates within different parts of the country. In a pioneering study, Bibek Debroy, Director at the Rajiv Gandhi Institute of Contemporary Studies and economist Laveesh Bhandari have 
developed scores for Indian states on variables such as investment environment, infrastructure, law and order, health, consumer market, etc.(Debroy and Bhandari, 2005). Using Per Capita Income as the dependent variable, we used a regression model to evaluate the influence of certain institutions variables on economic development of Indian states. Table 3 provides variable names, definitions, and data sources for Model 2. Results of regression for Model 2 are given in Table 4.

Table 1

Variable Definitions: Model 1

\begin{tabular}{ll}
\hline Variable & Definition \\
\hline GNIPerPPP05 & Gross national income per capita on purchasing power parity basis, year 2005 (1) \\
PubIndex & An index for quality of public institutions in a country (2) \\
MacrIndex & An index for macroeconomic stability in a country (2) \\
\hline
\end{tabular}

Sources: (1) World Development Indicators Database, World Bank, Washington D.C., July, 2006.

(2) The Global Competitiveness Report 2005-2006: Policies Underpinning Rising Prosperity,

World Economic Forum, Geneva, Switzerland.

The specification of the equation in Model is as follows:

GNIPerPPP05 = $\mathrm{f}($ PubIndex, MacrIndex $)$

Table 2

Regression Results: Model 1

\begin{tabular}{lll}
\hline Variables & Coefficient & T-statistic \\
\hline Intercept & -21991.76 & -8.338 \\
PubIndex & 3258.98 & $3.53^{*}$ \\
MacrIndex & 4434.83 & $4.38^{*}$ \\
\hline
\end{tabular}

$\mathrm{R}^{2}=.783$

$\mathrm{F}=67.377$

*Significant at the 0.01 level.

$* *$ Significant at the 0.05 level.

$* * *$ Significant at the 0.10 level.

Table 3

Variable Definitions: Model 2

\begin{tabular}{ll}
\hline Variable & Definition \\
\hline PCI & Per capita income in an Indian state in rupees (Year 2005) \\
Infra 05 & An index for quality of infrastructure in an Indian state (Year 2005) \\
L \& O & An index for quality of law and order in an Indian state (Year 2005) \\
Inv Env 05 & An Index for quality of investment environment in an Indian state (Year 2005) \\
\hline
\end{tabular}

Sources: Saran, Rohit, “India’s Best and Worst States,” India Today, LivingMedia, New Delhi, India, August, 2005.

The specification of the equation in Model 2 is as follows:

PCI $=\mathrm{f}($ Infra, L\& O, Inv Env)

Table 4

Regression Results: Model 2

\begin{tabular}{lll}
\hline Variables & Coefficient & T-statistic \\
\hline Intercept & 2581.41 & 1.52 \\
Infra 05 & 2115.72 & $2.58^{* *}$ \\
$\mathrm{~L} \&$ O 05 & 622.02 & 0.94 \\
Inv Env 05 & 2804.11 & $1.79 * * *$ \\
\hline $\mathrm{R}^{2}=.72$ & & \\
$\mathrm{~F}=13.56$ & & \\
*Significant at the 0.01 level. & & \\
$* *$ Significant at the 0.05 level. & & \\
$* * *$ Significant at the 0.10 level. & & \\
\hline
\end{tabular}




\section{CONCLUSIONS}

This paper has attempted to look at the role of institutions in growth of countries. It compared income and quality of institutions data among 87 developing countries to see if institutions that promote economic freedom and investment lead to higher economic growth. In addition, we wanted to look at the role of institutions at "micro" levels. We were interested in seeing if differences in quality of public institutions of local governments affected growth of different parts of a country. Since a nation's growth is sum of growth in different regions of a country, an analysis that shows regional growth is affected by quality of institutions in those regions will bolster the argument that quality of institutions play an important role in competitiveness and growth of countries. In Model 1 variables representing quality of public institutions in developing countries (PubIndex) and quality of macroeconomic policies in developing countries (MacrIndex) are significant at 0.05. In Model 2 the variable representing quality of infrastructure in an Indian state (Infra 05) is significant at 0.05 and the variable representing quality of investment environment (Inv Env 05) in an Indian state is significant at 0.10. Since investment environment is affected by quality of public institutions, we can conclude income level in Indian states is also influenced by having good quality public institutions. Thus, two models used in this paper show that the productivity and growth of a developing country is significantly affected by the quality of institutions in that country. These results should be useful for policy makers in developing countries promoting economic growth. The policy makers should concentrate in developing rules and regulations that improve the quality of public institutions in their countries.

\section{AUTHOR INFORMATION}

Dr. Tejinder S. Sara graduated in 1969 from California State University, Los Angeles, California with a Bachelor of Science degree in business and economics and worked in Southern California for two years with Mattel Inc. In 1974 Dr. Sara received a doctorate in economics from the University of Massachusetts at Amherst. Currently he holds the rank of Professor and the interim dean in the Brimmer College of Business and Information Science at Tuskegee University.

Dr. Alicia J. Jackson graduated in 1972 from Knox College with a Bachelor of Science degree in mathematics. In 1975 she received the MBA degree from the University of Michigan. After receiving the MBA degree, Dr. Jackson worked in the private sector and government agencies. In 1997, Dr. Jackson obtained a PhD degree from the University of Texas at Austin. She currently serves as the Dean of the Sigmund Weis School of Business at Susquehanna University in Pennsylvania.

Dr. Leo Upchurch graduated in 1964 from Paul Quinn College with a Bachelor of Science degree in natural science. He did graduate studies at the Illinois Institute of Technology and the University of Michigan. In 1982 he obtained a PhD degree from the University of Michigan, specializing in statistics and technological and environmental planning. He has taught at Pennsylvania State University, the Illinois Institute of Technology, and Florida Agricultural and Mechanical University. Dr. Upchurch currently holds the rank of Associate Professor of Economics in the Brimmer College of Business and Information Science at Tuskegee University.

Dr. Simran Kahai received the Bachelor of Arts degree in economics in 1987 from Panjab University, India. She received the Master of Science degree in economics in 1992 and a Ph.D. degree in economics in 1995. Both of the graduate degrees were obtained from Auburn University in Alabama. Dr. Kahai has taught at Tuskegee University and Kent state University. Currently she holds the rank of Associate Professor of Economics in the Department of Economics and Finance at John Carroll University, Cleveland, Ohio.

\section{REFERENCES}

1. Acemoglu, D, Johnson, S. \& Robinson, J. (2002). Reversals of fortune: Geography and institutions in the making of the modern world income distribution. Quarterly Journal of Economics, Vol. 117, 1231-1294.

2. Adkins, L.C., Moomaw, R.L. \& Savvides, A. (2002). Institutions, freedom, and technical efficiency. Southern Economic Journal. Vol. 69, No.1, 92-108.

3. Barro, R. J. \& Sala-i-Martin, X. (1995). Economic Growth. McGraw-Hill. 
4. Dawson, John W. (1998). Institutions, investment and growth: New cross country and panel data evidence. Economic Inquiry. Vol. 36, 603-619.

5. Debroy, B. \& Bhandari, L. (2005). Economic Freedom for States of India. Rajiv Gandhi Institute for Contemporary Studies, New Delhi.

6. De Soto, Hernando, (2000).The Mystery of Capital: Why Capitlism Triumphs in the West And Fails Everywhere Else. New York: Basic Books

7. Gwartney, J., Lawson, R. \& Block, W. (1996). Economic Freedom of the World, 1975-1995. Vancouver, Frasier Institute Press.

8. Hayek, Frederick V. (1944). The Road to Serfdom. London, Routledge Press.

9. Locke, J. (2003). Two Treatises of Government. London: Yale University Press.

10. North, Douglas C. (1990). Institutional Change and Economic Performance. New York, Cambridge Press.

11. Olson, M. (2000). Power and Prosperity: Outgrowing Communist and Capitalist Dictatorships. Oxford University Press.

12. Rodrik, D. (1997). The paradoxes of successful states. European Economic Review. 411-442.

13. Rodrik, D. (2000). Institutions for high-quality growth: What they are and how to acquire them. Studies in Comparative International Development, Vol35. No.3.

14. Rodrik, D. \& Subramanian, A. (2003). The primacy of institutions. Finance and Development. 31-34.

15. Saran, R. (2005). India's best and worst states. India Today, August, 2005.

16. Scully, Gerald W. (1988). The institutional framework and economic development. Journal of Political Economy, Vol. 96, 652-62.

17. Smith, A. (1994). An Inquiry into the Nature and Causes of the Wealth of Nations. New York: Random House.

18. $\quad$ World Bank (2006).World Development Indicators Database, Washington D.C.: World Bank.

19. World Economic Forum (2005). The Global Competitiveness Report 2005-2006: Policies Underpinning Rising Prosperity. Geneva, Switzerland: World Economic Forum. 